\title{
THE ROLE OF SOCIAL CAPITAL AND PARTICIPATION ON THE TECHNICAL EFFECTIVENESS OF IRRIGATION MANAGEMENT: A CASE STUDY OF NALAN DISTRICT IRRIGATION AREA
}

\author{
Listiani Reyna \\ Graduate Program, Syiah Kuala University Banda Aceh Indonesia \\ Hamid Ahmad Humam, Kasimin Suyanti \\ Faculty of Agriculture, Syiah Kuala University Banda Aceh Indonesia \\ *E-mail: reyna.listiani84@gmail.com
}

\begin{abstract}
Some of the most common challenges faced in irrigation systems are inefficient water usage because of damaged irrigation networks in various level and insufficient irrigation management. The objective of this study is to assess the role of social capital and participation towards technical effectiveness of irrigation management in Nalan Irrigation Area in Bireuen district. A common problem in the Nalan Irrigation Area is the large fluctuation of water discharge between the rainy and dry seasons. It is found that the existence of social capital will increase the participation in establishing the technical effectiveness of irrigation management.
\end{abstract}

\section{KEY WORDS}

Social capital, participation, technical effectiveness, irrigation, management.

Water is a basic resource that supports agricultural production activities. The existence of irrigation water and its system must be well-maintained and optimalized in achieving food security. According to Hasan (2005), so far, the contribution of irrigation development to food security is quite big; it is $84 \%$ of national rice production is sourced from irrigation area. Some of the common challenges faced in irrigation systems are irrigation networks that have been damaged under several jurisdictions and the lack of optimum irrigation management resulting in water utilization innefficiency. According to Direktorat Jenderal Sumber Daya Alam Kementrian Pekerjaan Umum (2015) about 53, 89\% of irrigation are in good condition, $13.30 \%$ in slightly damaged condition, at $16,84 \%$ were moderately damaged and $15.97 \%$ in severely damaged condition. The $80 \%$ damaged irrigation is the irrigation under the Province and Regency authorities.

Various problems occurred in irrigation management led the Government continues reforming irrigation management policy. In 2015, the Government issued the Decree of Peraturan Menteri PU dan Perumahan Rakyat No: 30/PRT/M/2015 on Farmer/P3A/GP3A/IP3A's participation in irrigation management which strengthens the institutional presence of Perkumpulan Petani Pemakai Air (P3A) and the Gabungan Perkumpulan Petani Pemakai Air (GP3A), (Direktorat Jenderal Sumber Daya Alam Kementrian Pekerjaan Umum, 2015). In the diversity of the Indonesian people, the consideration of the specificity of each local community and region in irrigation management should receive the main attention. Therefore, the local wisdom of irrigation management institution will be maintained, such as Subak in Bali, Lebak Lebung in South Sumatra, Tuwawa in East Java, Mitra Cai in West Java and Darma Tirta in Central Java while overseas local wisdom related to irrigation network management which is quite famous like Zanfera in Philippines, Shramadana in India, and Khageri in Nepal.

Independent irrigation management by $P 3 A$ is still constrained by the weak economic power both in the farmers' economic activities of and the implementation of irrigation management activities. The social capital in irrigation management that developed at $P 3 A-$ level becomes the determining factor of irrigation management sustainability. The research 
conducted by Rohmani et.al (2015) shows that social capital has a significant effect on the management of irrigation on the welfare of farmers in Sukoharjo District, Central Java Province. Alfiasari's research on social capital analysis in community-based business groups also shows the result that the adequacy of social capital affects the development of community-based economy in the form of groups (community).

According to Putnam (1995) the amount of social capital in a community has an influence on the improvement of various useful outputs to the community. According to Inayah (2012) the increased social capital will increase the community's participation in development programs and better local governance system. Increased community participation can be recognized by increasing public awareness of the surrounding environment and increased involvement in social organizations. According to Kasih (2007), a good social capital be able to establish good institutional performance as well. Kusumartono (2003) also stated that social capital plays a dominant role towards the implementation of optimal irrigation management. Social capital plays a role in regulating collective action and increasing participation in irrigation management. Farmer community participation / P3A in irrigation management will increase ownership, sense of responsibility and improve the ability of the community in establishing the technical effectiveness of irrigation management.

The most well-known irrigation area in Aceh is the Nalan Irrigation Area in Bireuen district. The Nalan Irrigation Area is an irrigation that becomes the authority of the Aceh Province with 2,130 acres land area. The challenges often faced in managing the Nalan Irrigation Area are the occurrence of large fluctuations between the rainy season and the dry season so that water rotation system should be applied in the dry season to meet the water for the planting area in this Irrigation Area. Farmers in Nalan irrigated areas plants two times a year and in the dry season the water discharge is decreasing and should do the applying the water rotation system per eight (8) hours to ensure the sufficient water availability to agricultural areas and social capital plays an important role here. Therefore, it is important to research the role of social capital and participation in the technical effectiveness of irrigation management in the Nalan District Irrigation Area Bireuen.

\section{METHODS OF RESEARCH}

The location of this research is located in the Nalan Irrigation area in Jeunieb SubDistrict, Bireuen District and which is the under the authority of Regional Irrigation Authority in Aceh. The objective of this research is a member of the Perkumpulan Petani Pemakai Air (P3A) located in the Nalan Irrigation Area, Jeunieb Sub-district, Bireuen District. The scope of this study is limited to social capital and participation in the technical effectiveness of irrigation management. The population in this research is all members of Perkumpulan Petani Pemakai Air (P3A) of Nalan District Irrigation Area Bireuen. Nalan Irrigation Area has 2,130 acres land area with 30 members of Perkumpulan Petani Pemakai Air (P3A) in 30 villages. Each P3A in the upstream, middle and downstream areas were taken again as many as 10 respondents of P3A members who are in the upstream, middle, and downstream as well. So from each member of P3A in upstream are 40 respondents, P3A member in middle part is 40 respondents and member of P3A downstream of 38 respondents. So the total respondents in this study are 118 respondents.

Data collection was done by structured interview through questionnaires that provides multiple answers, this questionnaire is used to obtain following data as: Social Capital Variable with three aspects (1) Trust, (2) Social Networking, (3) Social Norms, Participation Variable and Irrigation Technical Effectiviveness Variable. Respondents for data collection using questionnaires are farmers who are members of a Perkumpulan Petani Pemakai Air $(P 3 A)$ in Nalan Irrigation Area, Bireuen District. Operational limitation of research variables consist of the technical effectiveness of irrigation management as the dependent variable, participation as an intervening/mediating variable, and social capital as an independent variable. 


\section{RESULTS AND DISCUSSION}

The research was conducted in the Nalan Irrigation Area of Jeunieb Sub-district of Bireuen District which is geographically located at $4^{\circ} 54^{\prime}$ - at $5^{\circ} 21^{\prime}$ North Latitude and at $96^{\circ} 20^{\prime}$ - at $97^{\circ} 21^{\prime}$ East Longitude. Bireuen regency is adjacent to Malaka Strait in the north side, Bener Meriah and Central Aceh in the south side, North Aceh in the east side, and Pidie Jaya and Pidie in the west side. Nalan Irrigation Area is an irrigated area which has right and left intake which already has a main building (fixed weir), building site (tapped weir) and complementary buildings. Nalan Irrigation Area irrigating 2230 acres rice fields Jeunieb and Peulimbang sub-district. Nalan Irrigation Area takes water from the Nalan River and irrigates 30 villages including: Balee Daka, Tupin Panah, Matang Kule, Paloh Pupu, Lancak Bungo, Alue Seutui, Lhok Kulam, Ulee Blang, Uten Pupaleh, Blang Ruubok and Sampo Ajad. In Nalan Irrigation Area is hydrologically divided into three regions: upstream (upper stream), middle (middle stream), and downstream (lower stream).

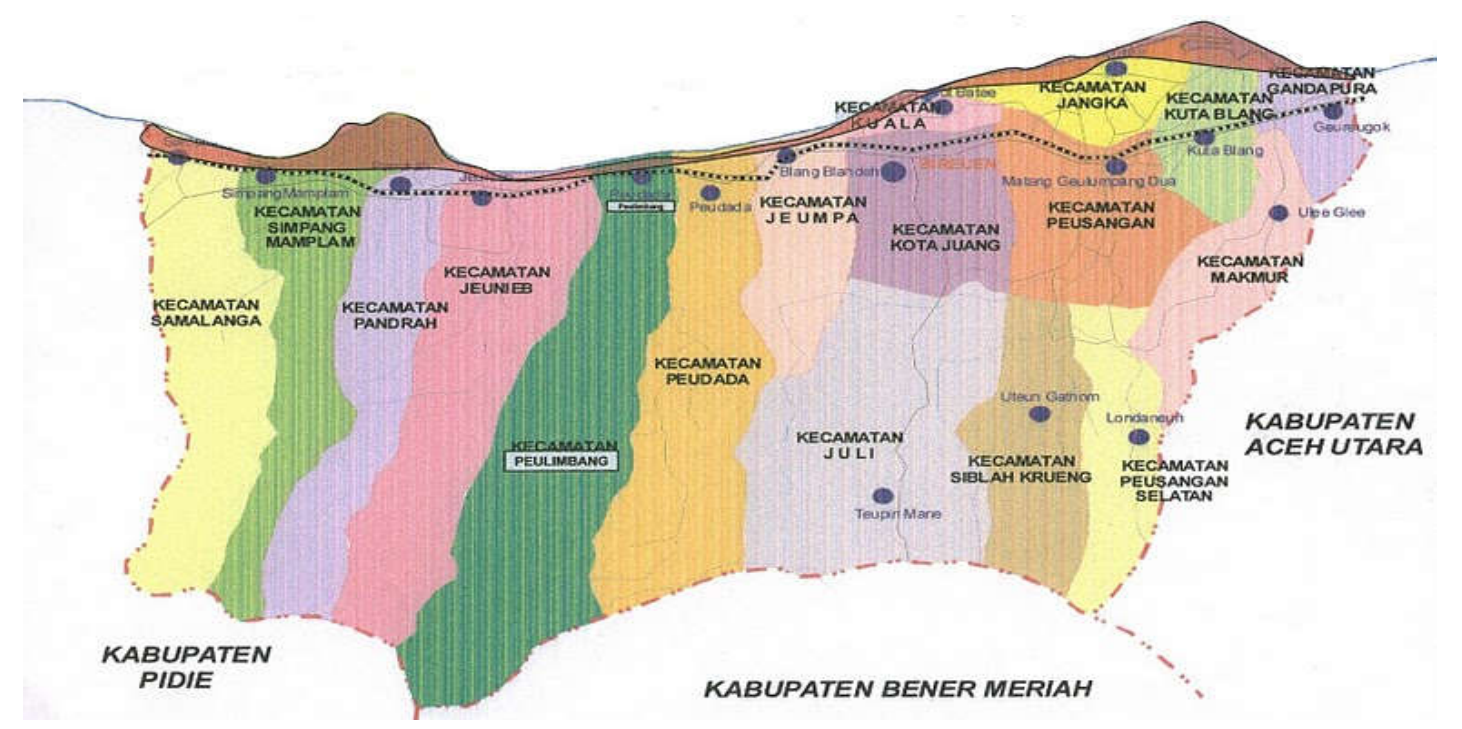

Figure 1 - Bireuen District

According to Badan Pusat Statistik (2009), the age can be classified as follows: young (<39 years old), middle-age (39-51 years old), and elders ( $>51$ years old). The age distribution of farmers in this study can be seen in Table 1 below:

Table 1 - The Age Distribution of Respondents

\begin{tabular}{ccccccccc}
\hline No & Age & $\begin{array}{c}\text { Cate- } \\
\text { gory }\end{array}$ & $\begin{array}{c}\text { Upstream } \\
\text { (person) }\end{array}$ & $\begin{array}{c}\text { Middle } \\
\text { (person) }\end{array}$ & $\begin{array}{c}\text { Down-stream } \\
\text { (person) }\end{array}$ & $\begin{array}{c}\text { Upstream } \\
(\%)\end{array}$ & $\begin{array}{c}\text { Middle } \\
(\%)\end{array}$ & $\begin{array}{c}\text { Down- } \\
\text { stream (\%) }\end{array}$ \\
\hline 1 & $\begin{array}{c}25- \\
38\end{array}$ & Young & 11 & 10 & 10 & 9.3 & 8.4 & 8.4 \\
& $\begin{array}{c}39- \\
28\end{array}$ & Adult & 18 & 17 & 19 & 15.25 & 14.4 & 16.10 \\
3 & $\begin{array}{c}49- \\
65\end{array}$ & Old & 11 & 13 & 9 & 9.3 & 11.01 & 7.6 \\
\hline
\end{tabular}

Source: Primary Data Processed (2018).

Based on Table 1 above, it can be seen that the age of active farmers as P3A members is dominated by adult category (39-48 years) in upstream hydrological area consisted of 18 people or $18.25 \%$ percents, in middle hydrological area consisted of 17 people or 14,4 percent and in downstream hydrological areas consist of 19 people or 16.10 percent. The activeness in the adult category as the member of $P 3 A$ is in accordance with Azwar (2016) which states that age has a direct effect on one's work productivity where the 
the severity of duties and responsibilities of $P 3 A$ members makes the community is dominated by members in adult category. The land area is crucial to be successfull in farming. Sajogyo (1977) as well as Badan Pusat Statistik (2009) classifies farmers in Java into three categories according to land ownership: small-scale farmers with farmland area $<0.5$ acres, medium scale with farming area of 0.5-1.0 acres, and large scale of farmland area> 1.0 acres.

Table 2 - The Land Aera Distribution of Respondents

\begin{tabular}{|c|c|c|c|c|c|c|c|c|}
\hline \multirow[b]{2}{*}{ No } & \multirow[b]{2}{*}{ Education } & \multirow[b]{2}{*}{$\begin{array}{l}\text { Cate- } \\
\text { gory }\end{array}$} & \multicolumn{3}{|c|}{ Hydrological Areas } & \multicolumn{3}{|c|}{ Hydrological Areas } \\
\hline & & & $\begin{array}{c}\text { Upstream } \\
\text { (person) }\end{array}$ & $\begin{array}{c}\text { Middle } \\
\text { (person) }\end{array}$ & $\begin{array}{c}\text { Down-stream } \\
\text { (person) }\end{array}$ & $\begin{array}{c}\text { Upstream } \\
(\%)\end{array}$ & $\begin{array}{c}\text { Middle } \\
(\%)\end{array}$ & $\begin{array}{c}\text { Down- } \\
\text { stream (\%) }\end{array}$ \\
\hline 1 & $\begin{array}{l}<0.5 \\
\text { acres }\end{array}$ & Small & 2 & 2 & 3 & 5 & 5 & 7.8 \\
\hline 2 & $\begin{array}{l}0.5-1 \\
\text { acres }\end{array}$ & Medium & 25 & 20 & 25 & 62.5 & 50 & 65.7 \\
\hline 3 & $>1$ acres & Large & 13 & 18 & 10 & 32.5 & 45 & 26.3 \\
\hline
\end{tabular}

Source: Primary Data Processed (2018).

The analysis of social capital and participation relations on the technical effectiveness of irrigation management is very important to be done to see how far the relationship between these variables affects each other.

Table 3 - Coefficient of Social Capital and Participation on Effectiveness Technical Management of Irrigation

\begin{tabular}{|c|c|c|c|c|c|}
\hline No & Path & $\begin{array}{c}\text { Unstandarrized } \\
\text { Beta }\end{array}$ & $\begin{array}{l}\text { Standarized } \\
\text { Beta }\end{array}$ & $\begin{array}{c}\mathrm{p}- \\
\text { value }\end{array}$ & Decision \\
\hline 1 & Social Capital towards Participation & 0.086 & 0.269 & 0.003 & Significant \\
\hline 2 & Participation towards Effectiveness & 0.415 & 0.355 & 0,000 & Significant \\
\hline 3 & Social Capital towards Effectiveness & 0.048 & 0.129 & 0.163 & NotSignificant \\
\hline 4 & $\begin{array}{l}\text { Social Capital through Participation } \\
\text { towards Effectiveness }\end{array}$ & $0.014 \& 0.404$ & $0.036 \& 0.345$ & 0,000 & Significant \\
\hline 5 & Trust towards Participation & 0.178 & 0.209 & 0.023 & Significant \\
\hline 6 & Trust towards Effectiveness & 0.102 & 0.267 & 0.267 & NotSignificant \\
\hline 7 & $\begin{array}{l}\text { Trust through Participation towards } \\
\text { Effectiveness }\end{array}$ & $0.030 \& 0.408$ & $0.030 \& 0.349$ & 0,000 & Significant \\
\hline 8 & & 0.162 & 0.267 & 0.003 & Significant \\
\hline 9 & $\begin{array}{l}\text { Network towards Effectiveness } \\
\text { Network through Participation towards }\end{array}$ & 0.042 & 0.060 & 0.520 & NotSignificant \\
\hline 10 & Effectiveness & $-0.27 \& 0.427$ & $-0.38 \& 0.365$ & 0,000 & Significant \\
\hline $\begin{array}{l}11 \\
12\end{array}$ & $\begin{array}{l}\text { Norms towards Participation } \\
\text { Norms towards Effectiveness }\end{array}$ & $\begin{array}{l}0.114 \\
0.158\end{array}$ & $\begin{array}{l}0.133 \\
0.158\end{array}$ & $\begin{array}{l}0.151 \\
0.088\end{array}$ & $\begin{array}{l}\text { NotSignificant } \\
\text { Significant }\end{array}$ \\
\hline 13 & $\begin{array}{l}\text { Norm through Participation towards } \\
\text { Effectiveness }\end{array}$ & $0.113 \& 0.398$ & $0.113 \& 0.340$ & 0,000 & Significant \\
\hline
\end{tabular}

Source: Primary Data Processed (2018).

Based on the analysis results in the table 3 above, it shows that social capital significantly influence the participation where the $p$-value is 0.003 , so the hypothesis is accepted because $p$-value $<0.005$. The effect in aggregate of social capital on participation can be seen from the value of standardiezed coefficients $B$ that is 0.269 . The value is used to see how much influence of social capital towards participation, where the influence of social capital in aggregate towards the participation is $26,9 \%$. This means that the participation variability can be explained by the of social capital variables in aggregate as big as $26,9 \%$. The relations of participation towards technical effectiveness of irrigation management according to the analysis results in the table above also shows that the participation give a significant effect on the technical effectiveness of irrigation management in which is the $p$ value is $0.000<0.005$. The influence of participation towards technical effectivity of irrigation management can be known from standardized coefficients $B$ value that is equal to 0,355 . 
The value is used to see how big the influence of participation towards technical effectiveness of irrigation management, where the influence value given is as big as $35,5 \%$.

The relationship of social capital in aggregate towards technical effectiveness of irrigation management showed no significant effect on technical effectiveness of irrigation management because its $p$-value is $>0,05$ which is 0.163 . The relationship analysis between social capital in aggregate through the participation towards technical effectiveness of irrigation management according to analysis results in the table above it shows that the in aggregate of social capital through participation significantly influence the technical effectiveness of irrigation management because its $p$-value is $<0.005$ which is 0.000 . The value of standardized coefficients $B$ is used to determine the relationship between the studied variables. Based on the value of standardized coefficient $B$ in the above table, it can be seen that the standradized value of coefficients $B$ for social capital is 0.036 and participation is 0.345 . Therefore, the increasing social capital it will also increase the participation towards technical effectiveness of irrigation management. An increase in social capital will increase the participation in technical effectiveness of irrigation management.

The increased participation contributed greatly towards technical effectiveness of irrigation management as big as $34,5 \%$. The result of this study indicates that there is no direct connection between the social capital towards technical effectiveness of irrigation management. The relationship of social capital towards technical effectiveness of irrigation management is mediated by the participation as an intervening variable. This is in accordance with Putnam (2000) arguments. He stated that social capital refers to the primary aspects of social organization such as trust, norms and social networks that allow the implementation of a more coordinated activities and community members can participate and cooperate effectively and efficiently to achieve common goals, and affect productivity individually or in groups.

Partial relations of Social Capital through participation towards technical effectiveness of irrigation management can be seen from the relationship of social capital aspects of trust towards participation which shows that trust gives significant effect towards participation. This is because $p$-value is $<0,005$ which is 0,023 . Based on the value of coefficient $B$ in the table above, it can be seen that the value of standradized coefficients $\mathrm{B}$ for social capital with the aspect of trust is 0.209 which means a positive relationship, which with an increase in social capital aspects of trust will increase participation by $20.9 \%$. The relationship of social capital dimension of social network also has significant effect towards participation with $p$ value $<0,005$ which is 0,003 . Based on the value of the coefficient $B$ in the table above, it can be seen that the value of stand a radized coefficients B for social capital with social network aspects is 0.267 which means a positive relationship, which with an increase in social capital social network aspects will increase the participation by $26.7 \%$.

Based on the results of this study, it can be seen that partial social capital which is the aspect of social networks can also directly affect the participation, but the amount of influence is smaller than the influence of social capital aggregate towards participation. The aspect of social norms has no significant effect towards participation in partial with its $p$-value $>0.005$ which is 0.151 . This indicates that social norms does not directly affect participation in partial but social norms along with the trust and social networks that establish social capital which contribute towards participation. Based on the results of this study, it can be seen that the partial social capital which is the aspect of social norms does not directly affect the participation. Based on the results of this study it can be seen that the partial social capital aspect which is trust can also have a direct effect on participation, but the amount of influence is smaller than the influence of social capital aggregate on participation.

The analysis of direct relationship between social capital aspects in aggregate towards technical effectiveness of irrigation management shows insignificancy. The analysis of the relation bertween partiaol social capital aspect which is trust is also insignificantly influence the technical effectiveness of irrigation management and social network also does not significantly influence the technical effectiveness of irrigation management. This is because $p$-value $>$ is 0.005 which is 0,520 . 
The aspect which is norm shows a significant effect on the technical technical effectiveness of irrigation management because its $p$-value is $<0.005$ which is 0.088 . From these results it can be seen that the norms can directly affect the technical effectiveness of irrigation management. Norm is one aspect of social capital and a source of cognitive social capital that can lead / guide people to take action by joining the irrigation management system. The result is consistent with Ostrom's opinion (1990) which states that the norms were awakened in the community led to the join resource management (common resources) more efficiently such as irrigation systems and rural land. From the value of standardized Coefficients $B$ by 0.158 it can be seen that social norms directly affect the technical effectiveness of irrigation management with contribution by $15,8 \%$. The direct effect of the norm on the technical effectiveness of irrigation management is smaller when compared to the effect of social capital and participation on the technical effectiveness of irrigation management.

The aspect of trust and participation shows a significant influence towards technical effectiveness of irrigation management with its $p$-value $<0,005$ which is 0.000 . From the value of standardized coefficients $B$ by 0.030 and 0.349 it can be seen how much influence of trust through participation affects the technical effectiveness of irrigation management. Trust gives effect of $3 \%$ towards participation and participation giving effect by $34,9 \%$ towards technical effectivity of irrigation management.

The analysis of Social networking aspect through the participation towards technical effectiveness of irrigation management showed a significant influence on the effectiveness towards technical effectiveness of irrigation management with its $p$-value is $<0.005$ which is 0.000 . The same thing also happened in the analysis of social norms through participation that has a significant effect on the technical effectiveness of irrigation management with $\mathrm{p}$ value is $<0.005$ which is 0.000 . For indirect effect of social norms through participation can be seen from standardized coefficient $B$ by 0,113 and 0,340 . This indicates that social capital and participation can give a direct or indirect effect to the technical effectiveness of irrigation management. Nasdian (2011) also stated that the level of public participation can influence and be influenced by various things, one of which is social capital. The result of this study is in accordance with research conducted by Wicaksono (2016). He stated that social capital will be able to provide direct or indirect influence on an implementation of activities through collective action that will grow participation in individuals can also increase one's participation.

\section{CONCLUSION}

Social Capital and Participation of Perkumpulan Petani Pemakai Air (P3A) members in Nalan Irrigation Area play an important role in water rotation system for the fulfillment of water needs in tertiary irrigation networks in establishing technical effectiveness of irrigation management.

Social capital consists of three basic aspects: trust, social networking, and social norms. The level of trust and social norms are in the high category indicating that members of $P 3 A$ in Nalan Irrigation Area still have a high trustworthiness and uphold the norm in conducting irrigation management activities, while social networks are classified as moderate because the P3A group has been long time vacant from institutional activities. The institutional revitalization must be carried out because there are members and group leaders who have passed away.

Social capital and participation can have a direct or indirect effect on the technical effectiveness of irrigation management. Social capital and participation are significantly related to the technical effectiveness of irrigation management. In accordance with the results of hypothesis testing it can be seen that social capital has a significant effect on participation with the value of standardiezed coefficients $B$ is 0.269 and participation significantly influence the technical effectiveness of irrigation management with the value of standardiezed coefficients $B$ is 0.355 . 
The relationship of social capital and participation to the technical effectiveness of irrigation management is partially mediation, which means that the existence of social capital will increase the participation in establishing the technical effectiveness of irrigation management.

\section{REFERENCES}

1. Alfiasari. (2004). Analisis Modal Sosial pada Kelompok Usaha Berbasis Komunitas: studi kasus di Kecamatan Pamijahan dan Kecamatan Cibungbulang Kabupaten Bogor. Tesis. Program Pascasarjana Institut Pertanian Bogor, Bogor.

2. Azwar. (2016). Persepsi dan Partisipasi Petani dalam Pelaksanaan Kegiatan Rehabilitasi Tanaman Kakao di Kabupaten Sigi Provinsi Sulawesi Tengah. Tesis. Program Studi IImu Penyuluhan Pembangunan Institut Pertanian Bogor. Bogor.

3. Badan Pusat Stastistik. (2007). Indikator Kesejahteraan Rakyat di Indonesia. Jakarta

4. Dinas Pengairan Aceh. (2017). Bidang Operasi dan Pemeliharaan Irigasi. Banda Aceh.

5. Dinas Pertanian dan Perkebunan Aceh. (2017). Bidang Prasarana dan Sarana Pertanian. Banda Aceh.

6. Hasan, M (2005). Bangun Irigasi Dukung Ketahanan Pangan. Majalah Air. Direktorat Jenderal Sumber Daya Air, Departemen Pekerjaan Umum, Jakarta.

7. Inayah. (2012). Peranan Modal Sosial dalam Pembangunan. Jurnal Pengembangan Humaniora. 12 (1): 1 - 7.

8. Kasih, Y. (2007). Peranan Modal Sosial Terhadap Efektivitas Lembaga Keuangan di Pedesaan (Studi Kasus di Provinsi Sumatera Barat). Fordema 7 (2): 197-209.

9. Kementerian PU dan Perumahan Rakyat. (2015). Direktorat Jenderal Sumber Daya Air. Kementerian PUPR. Jakarta

10. Kusumartono, H. (2003). Sinergi Modal Sosial, Modal Fisik, Modal Manusia dan Modal Alam dalam Pengelolaan Jaringan Irigasi oleh Perkumpulan Petani Pemakai Air (P3A/GP3A/IP3A).Tesis. Universitas Indonesia. Jakarta

11. Kusumastuti, A. (2015). Modal Sosial dan Mekanisme Adaptasi Masyarakat Pedesaan dalam pengelolaan dan Pembangunan Infrastruktur. Jurnal [internet]. [diunduh tanggal 1 Februari 2018 pukul 08.00 WIB. Vol 20 No 01. Dapat diunduh dari:http://journal.ui.ac.id/index.php/mjs/article/download/4740/pdf.

12. Nasdian, FT. (2006). Pengembangan Masyarakat (community development). Institut Pertanian Bogor. Bogor.

13. Ostrom, E. (1990). The Evolution of Institution for Collective Action. In: Elinor O, editor. Governing the Commons. United Kingdom: Cambridge University Press.

14. Pupitaningrum, E. (2017). Modal Sosial dan Partisipasi Masyarakat dalam Pembangunan Desa Wisata Tamansari di Kabupaten Banyuwangi. Skripsi. Institut Pertanian Bogor. Bogor

15. Putnam, RD. (1993). Making Democracy Work: Civic Tradition in Modern Italy. Princeton University Press. Princeton

16. (1995). Bowling alone: America's Declining Social Capital: www.muse.jhu.edu/demo/journal of democracy/v006/putnam.html.

17. Pretty, J \& Ward, H. (2001). Social Capital and the Environment. World Development 29 (2): 209-227.

18. Pretty, J. (2003). Social Capital and the Collective Management of Resources. Journal of Science. 32: 1912-1914.

19. Rolalisasi, A. (2008). Pola Partisipasi Masyarakat dalam Perbaikan Kawasan Permukiman Kumuh di Kelurahan Sukolilo Kecamatan Bulak Kota Surabaya, Thesis. Magister Teknik Arsitektur, Institut Teknologi Surabaya. Surabaya.

20. Rohmani SA, Rustiadi E, Firdaus M, \& Sudaryanto T. (2015). Dampak Modal Sosial dalam pengelolaan Irigasi terhadap Kesejahteraan Petani di Kabupaten Sukoharjo Jawa Tengah. Makalah Sekolah Pascasarjana Institut Pertanian Bogor. Bogor.

21. Sajogyo. (1977). Garis Miskin dan Kebutuhan Minimum Pangan. Lembaga Penelitian Sosiologi Pedesaan (LPSP). Institut Pertanian Bogor. Bogor. 
22. Vipriyanti, N.U. (2007). Studi sosial ekonomi tentang keterkaitan antara modal sosial dan pembangunan ekonomi wilayah studi kasus di empat Kabupaten di Propinsi Bali. Desertasi. Sekolah Pasca Sarjana, Institut Pertanian Bogor. Bogor.

23. Wicaksono, TN. (2016). Hubungan Partisipasi Petani pada Program Pengembangan Usaha Agribisnis Pedesaan terhadap Taraf Hidup Masyarakat.Skripsi. Departemen Sains Komunikasi dan Pengembangan Masyarakat, Fakultas Ekologi Manusia, Institut Pertanian Bogor. Bogor.

24. Winarni, I. (2011). Keterkaitan Antara Modal Sosial Dengan Produktivitas Pada Sentra Bawang Merah Di Kecamatan Pangalengan Kabupaten Bandung. TESIS. Program Magister Perencanaan dan Kebijakan Publik Ekonomi Perencanaan Kota dan Daerah. Universitas Indonesia. Jakarta.

25. Woolcock, M. (1998). Social capital and economic development: Toward a theoretical synthesis and policy framework. Theory and Society. 27 (92):151-208.

26. World Bank. (2003). Measuring Social Capital. Download dari http://www.worldbank.org/poverty/scapital. 